\title{
症型分類（顎関節研究会提案）からみた顎関節症患者の臨床的検討
}

\author{
成 辰熙・高木律男・大橋 靖
}

\section{Clinical evaluation of TMJ arthrosis according to new classification proposed by Japanese Society of Temporomandibular Joint}

\author{
Tatsuhiro SEI $\cdot$ Ritsuo TAKAgI Y Yasushi OHASHI
}

\begin{abstract}
TMJ arthrosis, who visited our clinic during two years from Dec. 1985 to Nov. 1987, were evaluated clinically according to a new classification proposed by Japanese Society of Temporomandibular Joint.

The patients consisted of 44 males and 118 females (sex ratio: $1: 2.68$ ), mean age was 35. 0 years with 8 to 70 year range.

1) The type distribution in our series was as follows; Type III was most commonly encountered (45.1\%) followed by Type II (29.6\%), Type IV (12.3\%), Type I (10.5\%), and Type V (0.6\%). The majority of Type I, IV were females.

2) The mean age was higher in Type IV (55.0 years) and Type I (47.2 years) than Type III (28. 7 years) and Type II ( 34.7 years).

3) The mean period before visiting our clinic was significantly shorter in Type I (6.8 months) than Type II (19.6 months), Type III (25.1 months) and Type IV (27.8 months).

4) The functional disturbance measured by dysfunction index was more severe in Type IV than other Types $(\mathrm{I} \sim \mathrm{III})$.

5) Effectiveness of standardized conservative treatment was reduced in the following order; Type I to Type IV.

6) In regard to complex type, it needs further study to determine its diagnostic criteria and application.
\end{abstract}

Key words: temporomandibular arthrosis (顎関節症), new classification (新分類), clinicostatistical study（臨床統計的研究）

緒 $\overline{\overline{\bar{n}}}$

顎関節症は臨床像を総括した診断名であり，さまさま

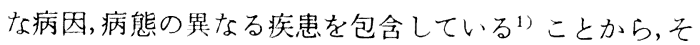
の病態像のとらえ方の違いにより従来から各研究者によ って多種多様の病名で呼ばれ，混乱も生じていた2

一方，近年の顎関節症に対寸る関節门板動態の解明を

新鼬大学选学部口腔外科学第 2 俩座

（主任：大橋 䄇教授）

Second Department of Oral and Maxillofacial Surgery, School of Dentistry, Niigata University (Chief: Prof. Yasushi Ohashi)

受付日：平成元年 7 月 25 日
はじめをする診断技術の著しい進歩によって，新なな知 見に立脚した病態分類が試みられるよらになり，昭和 61 年には䫇関節研究会から本症に対する新たな分類案 （以下，症型分類）が提示された.

また日も浅く，㬰際にこの症型分類に基ついて患者を 分類し，臨床的評価を加えたものは田ロ ${ }^{5,6)}$ の報告をみ るのみであり，今後十分に検討される必要があると思わ れる.

そもそも本分類は本来最終的なものではなく，多くの 臨床家によって使用されることによって変化していく可 能性を含んだものであるからである.

そこで今回わたくしたちは最近経験した罘関節症患者 をこの症型分類に基づき分類し，それをもとに臨床的検 討を行い，本分類の有用性について考察したので報告寸 る。 
表 1 研究対像

\begin{tabular}{c|c|c|c}
\hline 年 齢 & 男 性 & 女 性 & 計 $(\%)$ \\
\hline$\sim 9$ & 0 & 1 & $1(0.6)$ \\
$10 \sim 14$ & 8 & 13 & $21(13.0)$ \\
$15 \sim 19$ & 5 & 18 & $23(14.2)$ \\
$20 \sim 29$ & 9 & 25 & $34(21.0)$ \\
$30 \sim 39$ & 6 & 15 & $21(13.0)$ \\
$40 \sim 49$ & 4 & 14 & $18(11.1)$ \\
$50 \sim 59$ & 4 & 14 & $18(11.1)$ \\
$60 \sim 69$ & 5 & 9 & $14(8.6)$ \\
$70 \sim$ & 3 & 9 & $12(7.4)$ \\
\hline 計 & 44 & 118 & $162(100.0)$ \\
\hline
\end{tabular}

\section{研究対象ならびに方法}

昭和 60 年 12 月から同 62 年 11 月までの 2 年間に新潟大学 雨学部附属病院第 2 口腔外科を受診し, 顎関節症と診断 された 162 例を対象とした。性別は男性 44 例，女性118 例 (性比は $1: 2.68$ ). 年秢は 7 80 歳で平均 35.0 歳で ある(表 1).

これら患者の病歴, 臨床所見, 顎関節部X線所見（シ ューラー氏変法, 眼窩一下顎頭方向撮影, 矢状面断層X 線撮影）ならびに㴿関節腔造影検查所見（断層X線撮 影，X線テレビ）を総合して次の基準により症型分類を 行った. I 型: 咀嚼筋群および関連筋の疼痛, 罰運動障 害を主症状とし, 関節雑音や顎関節部の圧痛を認めない もの. II 型: 初発症状として関節雑音があってもその後 の経過や初診時には明瞭なクリッキングが認められず, 顎関節部の圧痛之運動痛を主症状とし, 慢性外傷性病变 が疑われるもの. II 型：顎関節腔造影所見で円板転位が 確認されたものや相反性クリックなどあきらかに円板転 位が疑われるもの. IV 型: 主症状の部位, 程度, 造影所 見には関係なく顎関節部X線検査にて, 粗造性変化, 辺 縁部骨增生像, 変形などの明らかな骨変化 ${ }^{7)}$ が認められ たもの. V 型：心身医学的要因が強く関与し， I $\sim V$ 型 に該当しないもの.

これらの基準により分類された各症型と以下の項目と の関連性について検討を加えた。
1) 年柃
2）初診までの期間
3) 機能障害度
4）治療成績

このらち機能障害度については, Helkimo ${ }^{8,9)}$ の機能 障害指数を参考に 3 段階の障害度を設定した。すなわ ち, 表 2 に示すよ 5 に䫇関節部疼痛, 顎関節部圧痛, 開 口障害, 䪽関節雑音, 筋の王痛の 5 症状についてその重 症度を基準に 0 点, 1 点, 2 点, 5 点の 4 段階の障害度
表 2 障害度スコア
$\mathrm{P}$ ：顎関節部疼痛, $\mathrm{D}$ ：顎関節部圧痛,
$\mathrm{T}$ ：開口障害, $\mathrm{S}$ ：雑音, $\mathrm{M}$ ：筋圧痛
$\mathrm{P}_{0}$ ：疼痛なし
$\mathrm{P}_{1}$ ：起末時, 過開口時なと時々桨痛支り
$\mathrm{P}_{2}$ ：顎狸動時汪ほ常に疼痛市り
$\mathrm{P}_{5}$ : 激痛あり, 䫇媈動が非常に困難
$\mathrm{D}_{0}$ ：圧痛なし
$\mathrm{D}_{1}$ ：違和感，軽度生痛
$\mathrm{D}_{2}$ ：中等度圧痛
$\mathrm{D}_{5}$ ：压痛著明，関節後方部压痛
$\mathrm{T}_{0}: 40 \mathrm{~mm}$ 以上
$\mathrm{T}_{1} .35 \mathrm{~mm}$ 以上
$\mathrm{T}_{2}: 30 \mathrm{~mm}$ 以上
$\mathrm{T}_{5}: 30 \mathrm{~mm}$ 末满
$\mathrm{S}_{0}$ : 㗱音なし
$\mathrm{S}_{1}$ : 時々あり
$\mathrm{S}_{2}$ : 可触性, soft click
$\mathrm{S}_{5}$ : 可聴性, crepitus
$\mathrm{M}_{0}$ ：筋王痛なし
$M_{1}$ ：違和感, 軽度王痛
$\mathrm{M}_{2}$ ：中等度圧痛
$\mathrm{M}_{5}$ ：生痛著明
（例）合計点： $\mathrm{P}_{2} \mathrm{D}_{5} \mathrm{~T}_{2} \mathrm{~S}_{0} \mathrm{M}_{1}=2+5+2+0+1=10$ 点

スコアを与え, 各症状の 合計点から軽度 $(1 \sim 4$ 点), 中等度 $(5 \sim 9$ 点), 高度 $(10 \sim 25$ 点) の 3 段階に分け, 症型との関連性について検討した。

結果

\section{1. 症型別頻度}

表了のごとく，四型が73例 $(45.1 \%)$ と最も多く, 次 いで II 型が 48 例 $(29.6 \%)$, IV 型が 20 例 $(12.3 \%)$, I 型 が 17 例 $(10.5 \%)$ であった、V 型は 1 例 $(0.6 \%)$ の で, 資料不足から分類不可能のものが 3 例 $(1.8 \%)$ で あった。

性別との関係では，I 型ならびに $\mathrm{N}$ 型ではそれぞれ17 例中15例，20例中18例が女性で占められており，II， II 型の性分布とは明らかに異なっていた（表了）.

\section{2. 症型と年齢}

症型別の平均年桧では III 型が28.7歳で最も若く,つい でII 型が34. 7歳, I 型が47.2歳, $\mathbb{V}$ 型が55. 0 歳の順で, 特に I 型, $\mathrm{I}$ 型では他の症型に比し, 明らか沉高龄者に 多い傾向を示していた（表 4)。また，平均年齢の比較 的低いII 型, II 型では 10 歳代と 20 歳代でそれでれ 49.0 \% $69.4 \%$ を占めていた。 
表 3 症型別頻度

\begin{tabular}{|c|c|c|c|}
\hline 症 型 & 男 性 & 女 性 & 例数 $(\%)$ \\
\hline I 型 & 2 & 15 & $17(10.5)$ \\
\hline II 型 & 17 & 31 & $48(29.6)$ \\
\hline III 型 & 21 & 52 & $73(45.1)$ \\
\hline IV 型 & 2 & 18 & $20(12.3)$ \\
\hline $\mathrm{V}$ 型 & 1 & 0 & $1(0.6)$ \\
\hline$?$ & 1 & 2 & $3(1.8)$ \\
\hline 計 & 44 & 118 & $162(100.0)$ \\
\hline
\end{tabular}

表 4 症型別年湛

\begin{tabular}{cc|c}
\hline 症 & 型 & 年秢 $($ mean $\pm \mathrm{SD})$ \\
\hline I & 型 & $47.2 \pm 18.1$ \\
II & 型 & $34.7 \pm 18.4$ \\
III & 型 & $28.7 \pm 16.5$ \\
IV & 型 & $55.0 \pm 19.3$
\end{tabular}

表 5 症型と初診までの期間

\begin{tabular}{cc|c}
\hline 症 & 型 & 期間(月) \\
\hline I & 型 & 6.8 \\
II & 型 & 19.6 \\
III & 型 & 25.1 \\
IV & 型 & 27.8
\end{tabular}

\section{3．症型と初診までの期間}

症型別に発症から当科初診をでの期閒をみると I 型が 平均 6.8 か月, II 型19.6か月, II 型25.1 力月, IV 型27.8 か月で I 型から V 型まで順次羅病期間が長くなっていた (表 5 ). なかでも, I 型が他の症型に比し, 有意に短か った $(\mathrm{p}<0.05)$.

\section{4. 症型と機能障害度}

障害度スコアは I 型が平均 7.2, II 型 6.9, II 型 7.0, IV型 9.4 で, IV型が他の症型に比し有意に高值を示した $(\mathrm{p}<0.05)$.

また，症型別の障害度分布では，I〜开型ではほぽ同 様な障害度分布を示し，中等度障害が多いのに対し，IV 型では軽度障害が少なく，比較的高度障䗉が多い傾向を 示していた（表6）.

\section{5. 症型と治療成績}

1) 治療方法

全例とも保存療法を行ったが，経過観察例を除くとそ の内訳は，単独療法が29例 (19.6\%) で他の119例(80.4 \%) には $2 \sim 6$ 種の治療法を系統的に組又合わせて行っ た（表7）。なかでも薬物療法，スプリントをそれぞれ
表 6 症型と障害度

\begin{tabular}{|c|c|c|c|c|c|}
\hline 障害度 & I 型 & $\begin{array}{l}\text { II 型 } \\
(\%)\end{array}$ & $\begin{array}{l}\text { III 型 } \\
(\%)\end{array}$ & $\begin{array}{l}\text { IV 型 } \\
(\%)\end{array}$ & 計 \\
\hline 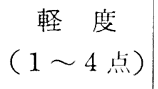 & $\begin{array}{c}4 \\
(23.5)\end{array}$ & $\begin{array}{c}14 \\
(29.2)\end{array}$ & $\begin{array}{c}17 \\
(23.3)\end{array}$ & $\begin{array}{c}2 \\
(10.0)\end{array}$ & 37 \\
\hline $\begin{array}{c}\text { 中等度 } \\
(5 \sim 9 \text { 点 })\end{array}$ & $\begin{array}{c}9 \\
(52.9)\end{array}$ & $\begin{array}{c}23 \\
(47.9)\end{array}$ & $\begin{array}{c}43 \\
(58.9)\end{array}$ & $\begin{array}{c}9 \\
(45.0)\end{array}$ & 84 \\
\hline 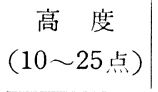 & $\begin{array}{c}4 \\
(23.5)\end{array}$ & $\begin{array}{c}11 \\
(22.9)\end{array}$ & $\begin{array}{c}13 \\
(17.8)\end{array}$ & $\begin{array}{c}9 \\
(45.0)\end{array}$ & 37 \\
\hline 計 & 17 & 48 & 73 & 20 & 158例 \\
\hline
\end{tabular}

表 7 治療法

\begin{tabular}{|c|c|}
\hline 治 療 法 & 延べ例数 $(\%)$ \\
\hline 薬物療法 & $95(59.3)$ \\
\hline ヘプリント & $94(58.0)$ \\
\hline 靧運動訓練 & $47(29.0)$ \\
\hline 理学療法 & $43(26.5)$ \\
\hline 咬合調整 & $29(17.9)$ \\
\hline 技 㳡 & $20(12.3)$ \\
\hline 義㳡調整 & $11(6.8)$ \\
\hline pumping & $26(16.0)$ \\
\hline manipulation & $21(13.0)$ \\
\hline 他科紹介 & $25(15.4)$ \\
\hline 経過観察 & $14(8.6)$ \\
\hline
\end{tabular}

約60\%の症例に用いた。

症型別では I 型と II 型では消炎鎮痛剤, 筋弛緩剤なと の薬物療法之前米ならびに全幽牙接触型スプリントを組 合せたものが多い。 III，IV型のらちクリッキングを伴う 症例には前方整位型スプリントを多く用い, 復位を伴わ ない円板前方転位すなわちクローズドロック症例ではす でに報告 ${ }^{10)}$ しように上関節腔パンピング、マンピュレ ーションを主体とし, 円板復位の有無により前方整位ス プリントや円板整位スプリント、開口訓練などを併用し た規格治療を行った。

\section{2）治療成績}

治療成績を通院中のものを除く117例についてみると， 自他覚症状の消失した完治が 28 例 (23.9\%), 自覚的症 状はないが他覚的に一部症状の残存するほぼ治㾌が19例 $(16.2 \%)$, 軽快か 48 例 $(41.0 \%)$, 不変 19 例 (16.2\%), 覀化 3 例 $(2.6 \%)$ であった（表 8$)$.

これを症型別にみると表 9 のごとく，完治とほぼ治痹 を治療奏効例とすると各症型の治療奏効率は I 型が 64.3 $\%$ ，II 型 $55.0 \%$ ，III 型 $29.2 \%$ ，IV型14.3\%であった。 た，これに軽快症例までを含め治療奏效例とすると，I 
表 8 症型と治療成結

\begin{tabular}{|c|c|c|c|c|c|}
\hline 成績 & I 型 & II 型 & III 型 & IV 型 & 例数 $(\%)$ \\
\hline 治 & 7 & 15 & 5 & 1 & $28(23.9)$ \\
\hline ほぼ治瘾 & 2 & 7 & 9 & 1 & $19(16.2)$ \\
\hline 軽 & 5 & 11 & 24 & 8 & $48(41.0)$ \\
\hline 不 & 0 & 6 & 8 & 5 & $19(16.2)$ \\
\hline 化 & 0 & 1 & 2 & 0 & $3(2.7)$ \\
\hline 計 & 14 & 40 & 48 & 15 & $117(100.0)$ \\
\hline
\end{tabular}

表 9 治療奏効率 $(\%)$

\begin{tabular}{cc|c|r}
\hline 症 & 型 & $\mathrm{A}$ & \multicolumn{1}{|c|}{$\mathrm{B}$} \\
\hline $\mathrm{I}$ & 型 & 64.3 & 100.0 \\
II & 型 & 55.0 & 82.5 \\
III & 型 & 29.2 & 79.2 \\
IV & 型 & 14.3 & 66.6 \\
\hline
\end{tabular}

A : 完治十ほほ治瘾

$\mathrm{B}$ ：完治十ほほ治瘾十軽快

型が $100 \% ，$ II 型 $82.5 \%$ ，III 型79.2\%， IV 型 66.6\% であ りどららも I 型から $\mathrm{V}$ 型へと順次奏効率が低下してい た。

\section{考察}

\section{1. 症型分類の診断基準について}

今回，研究方法にのべた基準で実際に患者を分類して みたが，まずI 型は主症状が明確なため診断は容易であ った。しかし，II 型と正型の鑑別はやや困難であった。 すなわち，今回顎関節内障が薙われる症例のらち40例に 腼関節造影を行ったが，造影を行っていない症例では II 型か III 型かの判定に迷5ものが10例あったＩI 型は関節 内軟部組織の損伤をまとめたものでおおよそ明確な外伤 由来のものとされている(1,4). しかし，現在の亡ころ損 傷の部位, 程度を明らかにする診断法が確立されて扣ら ず，診断が困難1,3) と指摘されており，特に内在性外伤 由来のものでは原因部位の確認が難しく，II 型としたも のの中に型が含まれてしまら可能性 ${ }^{3}$ も考えられる.

次に，吕型は造影所見で円板転位が確認されたもので は䛦断的に問題はないが，造影を行っていない症例でも 相反性クリックを有するものは大部分が円板前方転位を 示すことがあきらかにされている11,12)ことから型に含 めた。また， V 型については主症状の部位，程度，造影 所見には関係なく䫇関節部X線検査にて明らかな骨变化 が認められたものを選択した。

なお，今回の症型分類にあたっては，治療経過との関 連を知るらえで，できるだけ $I 〜 V$ 型のいずれかに当て
表 10 筋症状老有する頻度

\begin{tabular}{c|c}
\hline 症型 $(\mathrm{N})$ & 例数 $(\%)$ \\
\hline II $(48)$ & $17(35.4)$ \\
III (73) & $25(34.2)$ \\
IV (20) & $8(40.0)$ \\
\hline 計 (141) & $50(35.5)$ \\
\hline
\end{tabular}

表 11 筋症状の有無と治療替効率 $(\%)$

\begin{tabular}{cc|c|c}
\hline \multirow{2}{*}{ 症 型 } & \multicolumn{2}{|c}{ 筋 } & 症 \\
\cline { 3 - 4 } & $(+)$ & 状 \\
\hline II & 型 & 50.0 & 56.0 \\
III & 型 & 27.3 & 22.7 \\
IV & 型 & 20.0 & 14.2 \\
\hline
\end{tabular}

はめるよらに分類整理し，複合型は設けなかった。

\section{2. 症型別頻度について}

症型別頻度では四型が最も多く $(45.1 \%)$, 次いでI 型 $(29.6 \%)$, I 型 $(10.5 \%)$, IV 型 $(12.3 \%)$ の順でV 型は1例 $(0.6 \%)$ のみであった。

田ロ ${ }^{5,6)}$ の報告では红型 $(41.0 \%)$, II 型 $(11.4 \%)$, I 型 $(9.0 \%), \quad \mathrm{V}$ 型 $(8.4 \%), \mathrm{V}$ 型 $(2.4 \%)$ で，著者 らの結果と比較しII 型の頻度に差はあるものの各症型の 頻度順位は同様である。しかし，複合型が $27.7 \%$ あった とし, そのらち約 7 割は I 型と各型の組合せの症例であ るが，それ以外に II + II 型， II + IV 型， I + I + II 型な どを分類している.

これら複合型について, 症型分類案には「症状により $I+I I$ 型，I+II 型，I+IV 型などの複合型も存在する と考えられる」との記載があり，筋症状を主症状とする I 型との組合せを念頭に置いた表現となってはいるが, その診断基準や I 型以外の各型との組合せが許されるの かどらかについては明確にされてはいない.

先にも述べたように今回わたくしたちは複合型を分類 せず，主症状をもとに $\mathrm{I} \sim \mathrm{V}$ 型に分類整理したが，ちな みに表10は今回の症例でII ～IV型における等症状を有す る患者の頻度を㕛たもので，いずれも34.2 40.0\%で， これらをそれぞれ I + II 型，I＋II 型，I＋IV型などの 複合型に分類すると約 $1 / 3$ が複合型と分類できることに なる。

本症患者の筋症状の頻度について石橋 ${ }^{13)}$ は約半数に認 められたとし, 岡 $\left.{ }^{14}\right)$ は翌形性顎関節症の約 $42 \%$, 他の症 型では約 $30 \%$ と報告, 藍 ${ }^{15)}$ は補経領域における顎機能異 常者に拈いて触診で66\%に外側翼突筋に王痛を認めたと して扣り本症において筋の機能障害が深く関与している と報告している．以上のごとく筋症状は本症の随伴症

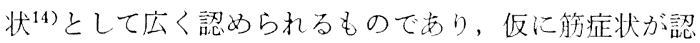


められるものをすべて I 型と各型の複合型とすると, 症 型分類の持つ本来の簡潔性を損ならことになるとも考兄 られる。このように複合型の診断基準とその取扱につい ては今後さらに検討を要すると考えられた。

\section{3. 性, 年齢との関係について}

対象症例の性比は $1: 2.68$, 年龄分布は 20 歳代を中心 とし全年龄層汇分布して扰り，すで報告した当科括 ける多数例 (509 例) での臨床統計的観察 ${ }^{16)}$ や他の臨床 統計17 19)の結果とほぼ同様であることから，特に対象患 者の性，年夦分布に偏りはないものと考えられた。

症型別にみると, 性別は I 型と N 型では全体の性比と 比較して圧倒的に女性に多かった。 しかし，田口5)の報 告ではこのよらな傾向は認めておらず, その理由は明ら かではない.両型とも症例数が比較的少ないことから単 純に推論はできないか，IV型については買関節の骨変化 が女性に多い19)ことと関連しているとも考えられる。

一方，年齢との関係ではIV型が高秢者に多かったが， これは田ロ吕の報告とも一致しているところである。こ れは顎関節に骨変化を伴らいわゆる変形性龥関節症が高

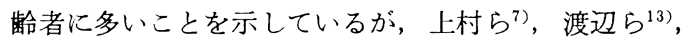
高橋ら²も本症患者では高齢者に骨変化をきたするのが 多いとしている.しかし，これらの報告では骨変化は各年 代にもみられるとしており，この点では骨変化が認めら れるものをすべて退行性病変ありと䛦断しIV型とするの が妥当かは今後検討されるべきと考兄られた．

次に， II， II 型では10歳代，20歳代に多かった。これ は田口 ${ }^{5,6)}$, 田口ら ${ }^{20)}$ も一致して認めており, その理由 としてこの年代では不正咬合や歯数の異常などの内在的 要因などにより発症するものが多いためと指摘している か，今後さらに詳細な分析が必要である。

\section{4. 初診までの期間との関係について}

今回対象とした患者の約 $80 \%$ は他科を経由して扣り， 初診までの期間をそのまま罹病期間とみなすことには問 題が残るが，他科での治療期間などを考虑に入れても特 にI 型では平均 6.8 か月と他の症型（19.6２7.8か月） に比し, 初診までの期間が短かく, 筋症状を主症状とす る患者では，早期に受診していることが䚐えた。この点 について，患者の受診動機に関連すると考兄られる初発 症状ならびに主訴をみると, 両者とも I 型, II 型では疼 痛が多いのに対し， II 型，IV型では䫟関節雑音で初発 し, 疼痛を主訴に来院するものが多く，雑音で初発する ものでは比較的受診が遅くなることを示していた。

\section{5. 治療成績との関係について}

症型別の治療成䋶では I 型からIV型へと順次治療奏効 率が低下しており，I 型や II 型に比し， III，IV型では効 果的治療の困難性を示していた，本来，症型分類は主症 状を基本に分類し, 重症度や治療に対する反応は配虑さ れていないと思われるが，このように症型によって治療 成績が明らかに異なるといら点では, 症型分類の有用性
が示されていると考えられる。

III，IV型では関節円板の著しい変形やクローズドロッ ク症例, 骨変化を有する症例など病態の進行したものが 含まれており，従来から保存療法では必ずしも十分な結

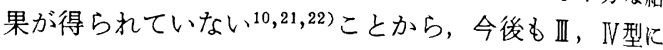
対する治療が問題となってくるものと思われる.

一方, 前述した複合型の取扱に関連して, 症型別湤 症状を有する群と有しない群に分け治療有効率をるる と, 表11のごとく両群ともほぼ同様な值を示していた， このことは筋症状の有無は治療に対する反応性に影響し ておらず，筋症状を随伴していても複合型と分類せず， 主症状をもとに II 〜 N 型のいずれかに分類しても，臨床 上不都合はないことを示しているものと思われる.

\section{結語}

昭和 60 年 12 月から同 62 年 11 月までの 2 年間に当科を受 診し，顎関節症と診断された 162 例に対し，頻関節研究 会による㴿関節症の症型分類に基づき患者を分類し, 種 々臨床的検討を行い，以下の結果を得た。

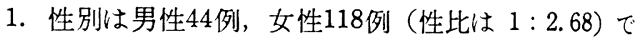
あった，年齢は $7 \sim 80$ 歳で平均 35.0 歳であった.

2. 症型別頻度は型が 73 例 (45.1\%) と最も多く, 次いでII 型48例 $(29.6 \%), \mathbb{V}$ 型20例 (12.3\%), I 型17 例 $(10.5 \%)$ でV型は1例 $(0.6 \%)$ のみであった，1 型，IV型では女性が大多数を占めていた。

3. 症型別の平均年齢は II 型が 28.7 歳で最も若く, 次 いで II 型 34.7 歳, I 型 47.2 歳, IV 型が55. 0歳, 特に I 型, IV 型では他の症型に比し, 明らかに高龄者に多かっ た。

4. 発症から 当科初診までの期間はI 型が平均 6.8 か 月， II 型19.6か月， III 型25.1か月， IV 型27.8か月で I 型 からIV型まで順次眻病期間が長くなっていた。

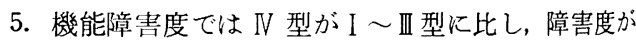
高い傾向を示していた。

6. 治療成績では I 型から IV 型へと順次治痛率が低下 していた.

7. 複合型の䛦断基準やその取扱いについては,さら に検討されるべきと考えられた。

本論文の要旨は第33回日本口腔外科学会総会 (1988年 9 月, 名古屋) 扣上び昭和63年度新潟桏学会第 2 回例会 （1988年11月，新潟）に扮いて報告した。

\section{引用 文 献}

1）岡達：䫇関節疾患の分類と頱関節症の位置 つけ. 日外誌 33：1066-1070 1987.

2）高橋庄二郎, 柴田考典: 顎関䬣症の基礎と臨 
林、第 1 版，医㳡薬出版，東京， 1979 .

3) 木野孔司：罘関節内障の概念。料科シャーール 29: 369-380 1989.

4）買関節症に関する小委員会：䪽関節症の分類 案。䫇関節研究会誌 7: 1361987.

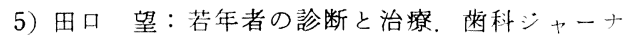
ル 29: 495-509 1989.

6）田口 望：症型分類による顎関節症の考之方拧 よび治療法。㮸界展望 71：969-979 1988.

7）上村修三郎，中村太保，他：䪽関節疾患に関与 るX楾訩断学的研究一顎関節症に扣ける関節の 形態的変化について一、蔽放 19:224-237 1979.

8) Helkimo, M.: Studies on function and dysfunction of the masticatory system. II. Index for anamnestic and clinical dysfunction and occlusal state. Swed Dent J 67: 101-121 1974.

9) Helkimo, M.: Studies on function and dysfunction of the masticatory system. III. Analysis of anamnestic and clinical recording of dysfunction with the aid of indices. Swed Dent J 67: 165-173 1974.

10）成辰㫮, 高木律男, 他：クローズドロックを 呈する顎関節症患者に対する保存治療の評価。 口科誌 38：283-291 1989.

11）米津博文：X線テレビシステムを用いる上下関 節腔造影検査による顎関節症患者の関節门板動 態異常に関する研究。㐘科学報 87：1613-1639 1987.

12）高木律男, 大橋 靖, 他：顎関節腔造影法に上
る顎関節症の臨林的検捨一とくに臨床所見と関 節円板動態の関連性について一。 日外誌 35 : 361-366 1989.

13）石橋克禮：筋・筋膜疼痛機能障害症候群々顎関 節内障一その機能異常の様相について一。 日 外誌 33: 1071-1078 1987.

14）岡達：䫇関節症の研究一成因および臨床像 を中心に一。科誌 16：116-123 1967.

15）藍和：䫇口腔系の機能異常にみられる痛み の部位について。補綴誌 17：133-137 1973.

16）成辰熙，小松䝨一，他：当科に扣忛る顎関節 症患者の臨床統計的観察。新潟菌学会誌 18: 23-32 1988.

17) 藤田 寛, 金井義明, 他：顎関節症の臨休的研 究第 1 報 臨床統計的観察。日口外誌 26 : 98-104 1980.

18）田口 望, 丸山高広, 他 : 顎関節症の臨床統計 的研究. 日口外誌 32: 399-405 1986.

19）渡辺八重子, 永瀬守, 他：顎関節症の臨床統 計的検討。新潟歯学会誌 18：77-85 1988.

20）田口 望, 峰野泰久, 他：いま若年者の顎関節 症が增えている。㮸界展望 69:1489-1502 1987.

21）和嶋浩一，木津真庭，他：顎関節内障（closed lock）の保存的療法に関する研究一lock 期間と 関節円板変形の関連について一。 、科誌 37 : 934-943 1988.

22）戸塚靖則，澤田 明，他：復位を伴わない関節 円板前方転位に対する治療法の検討。日口外誌 34: 1325-1337 1988 . 